\title{
Growth, Yield and Grain Nutritional Quality in Three Brazilian Pearl Millets (Pennisetum americanum L.) with African or Indian origins
}

\author{
LEONARDO O. MEDICI ${ }^{1}$, FABÍOLA V. GONÇALVES ${ }^{2}$, MARCOS PAULO S. DA FONSECA ${ }^{2}$, SALETE \\ A. GAZIOLA ${ }^{3}$, DAIANA SCHMIDT ${ }^{4}$, RICARDO A. AZEVEDO ${ }^{3}$ and CARLOS PIMENTEL ${ }^{2}$ \\ ${ }^{1}$ Departamento de Ciências Fisiológicas/IB, Universidade Federal Rural do Rio \\ de Janeiro, BR 465, Km 47, 23897-000 Seropédica, RJ, Brazil \\ ${ }^{2}$ Departamento de Fitotecnia/IA, Universidade Federal Rural do Rio de Janeiro, \\ BR 465, Km 47, 23897-000 Seropédica, RJ, Brazil \\ ${ }^{3}$ Departamento de Genética, Escola Superior de Agricultura “Luiz de Queiroz”, Universidade \\ de São Paulo, Avenida Pádua Dias, 11, 13418-900 Piracicaba, SP, Brazil \\ ${ }^{4}$ Departamento de Ensino, Pesquisa e Extensão, Instituto Federal de Santa Catarina, Rua \\ Aloísio Stoffel, 1271, Jardim Alvorada, 89885-000 São Carlos, SC, Brazil
}

Manuscript received on June 30, 2017; accepted for publication on December 1, 2017

\begin{abstract}
In this study, we are presenting recommendations to the best agricultural use as well as for plant breeding of three millet cultivars namely ENA1 and ENA2, which have African origin, and BRS1501 originally from India. These cultivars were evaluated for growth, yield and grain quality traits. The morphological traits evaluated in this study indicated that the African genotypes ENA1 and ENA2 are better than the Indian genotype BRS1501 for no-till farming or to produce forage with $15 \%$ of crude protein at flowering and at harvest to produce stover (around 7\% of crude protein content) for livestock feeding. The BRS1501 cultivar exhibited the highest values for total crude protein, albumins and prolamins, phytate and mineral contents in grains. ENA1 and ENA2 exhibited the highest values of globulin and glutelin contents. The electrophoretic patterns for storage proteins were similar across the three millets cultivars, except for a higher intensity of two glutelin bands with 21 and $24 \mathrm{kDa}$ in BRS1501. Together, the results allow us to recommend BRS1501 for grain production and ENA1 and ENA2 for biomass production.
\end{abstract}

Key words: mineral density, SDS-PAGE, phytate, seed storage proteins, amino acids.

\section{INTRODUCTION}

Pearl millet (Pennisetum glaucum L.) is the sixth most important cereal worldwide and it is a staple food for around 90 million people in the Sahelian region of Africa and northwestern India (Pattanashetti et al. 2016). Pearl millet is a $\mathrm{C}_{4}$

Correspondence to: Fabíola Vieira Gonçalves

E-mail: fabiolaufrrj@gmail.com plant with very high photosynthetic efficiency, dry matter production capacity, short life cycle, and high degrees of tolerance to heat and drought (Bidinger et al. 2009). It is also adapted on saline, acidic and aluminum toxic soils (Bidinger et al. 2009). Therefore, this cereal is cultivated and used as a grain and a forage crop and is the major cereal crop species for people living in the drier 
areas of the Indian subcontinent and in both West and East Africa. Yet, until very recently, pearl millet received comparatively to other crops, little attention from the scientific community (Pattanashetti et al. 2016). Pearl millet has also been shown to be a good option for no-till farming due to its high biomass production even without fertilization (Pimentel et al. 2003). Furthermore, pearl millet can be cultivated in a low-input agrosystem, without costly agronomic practices during its 90 days cycle, producing higher biomass and crude protein content (around 15\%) for forage than maize and sorghum (A.C.T. Costa, unpublished data, Pimentel et al. 2003). In Brazil, for instance, there is an important increase in pearl millet use for no-till farming but also in crop rotation, during the dry season, and for stover and grain production for animal feeding. Moreover, its grain is substituting maize in manufacturing chicken feed because of its higher protein content per kilo of grains produced at a lower cost than maize (Pimentel et al. 2003). The grain protein of pearl millet is characterized by a higher quality among cereals because lysine and tryptophan deficiency is diminished when compared to the majority of cereal crop seeds, and it is a "high-energy" cereal that contains carbohydrates, protein, oil and is rich in vitamins $\mathrm{B}$ and $\mathrm{A}$, high in calcium, iron, and zinc, and also contains concentrations of potassium, phosphorus, magnesium, zinc, copper and manganese (Bidinger et al. 2009, Pattanashetti et al. 2016).

The main center of origin and domestication of pearl millet is the West African region (Bidinger et al. 2009), but it was later introduced into India, which is nowadays considered a second origin center (Pattanashetti et al. 2016). Nevertheless, there is considerable diversity between African and Indian pearl millet genotypes, which have been evaluated and confirmed by morphological, isozyme and DNA analyses (Pattanashetti et al. 2016). The African genotypes have a higher crop growth rate, they are taller and produce more biomass, with a lower number of fertile tillers than the Indian ones, but both have the same grain yield potential (A.C.T. Costa, unpublished data). For livestock feeding, the African genotypes cultivated in Brazil can be harvested at the flowering stage for forage yield as ray or silage. When harvested at the milk stage the grain of pearl millet has 27 to $32 \%$ more protein than maize and its biomass is higher in weight and protein content (Pimentel et al. 2003). On the other hand, pearl millet can be harvested for forage at the end of the cycle because its stover crude protein content is still very close to $7.0 \%$, which is considered the minimum level required for cattle maintenance, but also producing grains to be used for chicken feed (Pimentel et al. 2003). However, studies on pearl millet grain quality traits are still scarce (Saleh et al. 2013).

In Brazil, Indian derived millets such as BRS1501 (Pereira Filho et al. 2003), and African derived such as ENA1 and ENA2, are available and have been cultivated (Pimentel et al. 2003). Thus, in this study, these cultivars were chosen because they represent the two main centers of origin of millet. We have compared the biomass and quality grain traits for these three millet cultivars aiming to present recommendations as to the best agricultural uses for them, as well as to present recommendations for plant breeding. The biomass and grain traits evaluated were biomass at flowering and maturity and the contents of storage protein fractions, phytate and minerals in grain.

\section{MATERIALS AND METHODS}

\section{PLANT MATERIAL}

The pearl millet cultivars ENA1, ENA2 and BRS1501 were grown in Seropédica, RJ, Brazil $\left(22^{\circ}\right.$ $\left.45^{\prime} \mathrm{S}, 43^{\circ} 41^{\prime} \mathrm{W}\right)$ during the rainy season. ENA1 and ENA2 were selected from African genotypes (A.C.T. Costa, unpublished data), while BRS1501 was selected from Indian genotypes (Pereira Filho et al. 2003). The experimental design was in blocks 
completely randomized with three replications for each of the three cultivars (treatments). Each plot consisted of a $7.5 \mathrm{~m}^{-2}$ area with 30 plants in five rows of $3.75 \mathrm{~m}$, spaced $0.5 \times 0.5 \mathrm{~m}$ apart, using 12 plants for sampling in the three central rows. The trial was conducted without fertilization in a Haplaquult soil, with the following composition in the first 0.2 m depth: pH: 5.6, $0.53 \%$ of $\mathrm{C}, 1.4 \mathrm{mmol}_{\mathrm{c}} \mathrm{dm}^{-3}$ of $\mathrm{Ca}, 0.7 \mathrm{mmol}_{\mathrm{c}} \mathrm{dm}^{-3}$ of $\mathrm{Mg}, 0.0 \mathrm{mmol}_{\mathrm{c}} \mathrm{dm}^{-3}$ of $\mathrm{Al}$, $70 \mu \mathrm{g} \cdot \mathrm{g}^{-1}$ of $\mathrm{K}$, and $12 \mu \mathrm{g} \cdot \mathrm{g}^{-1}$ of P. The field was irrigated only for seed germination with no others agronomic practices during the cycle of the plants. During the 95 days until final harvest the average mean temperature was $27^{\circ} \mathrm{C}$, precipitation was 346 $\mathrm{mm}$ and evaporation was $502 \mathrm{~mm}$. At flowering, three plants of each cultivar were harvested and the following parameters only in the above ground tissues were measured: shoot fresh and dry weights (dry weight was obtained after drying at $65^{\circ} \mathrm{C}$ for $72 \mathrm{~h}$ ), and at harvest, three other plants of each cultivar were harvested for shoot fresh and dry weight evaluation but also for the determination of grain yield, plant height, number of panicles per plant, mean size of panicles and cycle duration until maturity. The whole mature grains were lyophilized and a fine homogenate flour was produced and used in all grain quality measurements.

\section{PROTEIN EXTRACTION}

The method described by Landry and Damerval (2000) with some adaptations was used. Protein fractions extractions were performed using centrifuge tubes $(2.0 \mathrm{~mL}$ capacity) with $0.3 \mathrm{~g}$ of flour and $1 \mathrm{~mL}$ of solvent at each step. All centrifugations were performed at $12000 \mathrm{~g}$ for 5 min. The sequential protein fraction extraction used was as follows: a- two steps of defatting with hexane, b- two globulin extractions with $\mathrm{NaCl} 0.5$ mol L $\mathrm{L}^{-1}$, c- two albumin extractions with distilled water, d- one prolamin extraction with 2-propanol $55 \%(\mathrm{w} / \mathrm{w})+2$-mercaptoethanol $0.6 \%(\mathrm{v} / \mathrm{v})$, e- two glutelin extractions with dodecyl sulphate sodium $0.5 \%(\mathrm{w} / \mathrm{v})$ and 2- mercaptoethanol $0.6 \%$ $(\mathrm{v} / \mathrm{v})$ in sodium borate buffer $\mathrm{pH} 10\left(\mathrm{Na}_{2} \mathrm{~B}_{4} \mathrm{O}_{7} 12\right.$ $\mathrm{H}_{2} \mathrm{O} 0.0125 \mathrm{~mol} \mathrm{~L}^{-1}$ and $\mathrm{NaOH} 0.02 \mathrm{~mol} \mathrm{~L}^{-1}$ ). The centrifugations for defatting and for extraction of prolamins and glutelins were performed at room temperature, $25{ }^{\circ} \mathrm{C}$, while the other extractions for albumins and globulins were performed at 4 ${ }^{\circ} \mathrm{C}$. The protein supernatant was retrieved after centrifugation and when two centrifugations were performed, both supernatants were combined and stored at $-80{ }^{\circ} \mathrm{C}$.

Each protein fraction content was determined according to Bradford (1976). Nitrogen content was determined by the Kjeldahl method with a conversion factor of 6.25 for crude protein content (Pimentel et al. 2003).

\section{SDS-POLYACRYLAMIDE GEL ELECTROPHORESIS (PAGE)}

Electrophoretic analysis was carried out under denaturing conditions $(0.1 \%(\mathrm{w} / \mathrm{v}) \mathrm{SDS})$ in $13 \%$ polyacrylamide gels, with $3.8 \mu \mathrm{g}$ of protein loaded onto each lane for albumins and $5.0 \mu \mathrm{g}$ for the other storage protein fractions and the running conditions as described by Schmidt et al. (2015, 2016). The gels were prepared and stained with a solution of silver nitrate according to Blum et al. (1987).

\section{PHYTATE CONTENT}

Phytate extraction was carried out using a $250 \mathrm{mg}$ sample of flour in $10 \mathrm{~mL}$ of $2.4 \%$ hydrochloric acid for $3 \mathrm{~h}$ at room temperature with constant agitation. The samples were clarified by centrifugation at $6,000 \mathrm{~g}$ for $20 \mathrm{~min}$ at room temperature. The supernatant was applied and eluted from an anionexchange resin (Dowex1x8-400 Sigma) and the phytate determination was based on the colorimetric assay described by Latta and Eskin (1980). The assay was performed with $2.0 \mathrm{~mL}$ of Wade reagent $\left(0.03 \%(\mathrm{w} / \mathrm{v}) \mathrm{FeCl}_{3}\right.$ and $0.3 \%$ sulfosalicylic acid) and $3.0 \mathrm{~mL}$ of the eluted sample. Phytate contents 
of these solutions were determined at $500 \mathrm{~nm}$ using a spectrophotometer.

\section{TOTAL AMINO ACIDS EXTRACTION AND DETERMINATION}

The total amino acids were extracted through acid hydrolysis according to Fountoulakis and Lahm (1998) using $22.5 \mathrm{mg}$ of protein of a fine and homogenous flour and $9 \mathrm{~mL}$ of $6 \mathrm{~N} \mathrm{HCl}$. Prior to the hydrolysis, the oxygen was removed from the tubes by a vaccum pump. For this, we were used hydrolysis tube with side outlet for vacuum, and screw cap for teflon sealing. Afterwards, the samples were incubated at $110{ }^{\circ} \mathrm{C}$ for $22 \mathrm{~h}$ in a dry bath. After cooling the hydrolysis tubes to room temperature, the tubes were opened and the contents transferred to a volumetric flask and the volume adjusted with Milli-Q water to $25 \mathrm{~mL}$. The samples were filtered in $0.2 \mu \mathrm{m}$ millex and $200 \mu \mathrm{L}$ were transferred to a new tube and kept in desiccator with silica gel under vacuum until complete evaporation of the solvent. Samples were reconstituted in $20 \mu \mathrm{L}$ of $20 \mathrm{mM} \mathrm{HCl}$.

A volume of $10 \mu \mathrm{L}$ was derivatized in $70 \mu \mathrm{L}$ of borate buffer and $20 \mu \mathrm{L}$ of derivative agent (AccQfluor) according to the manufacturer's instructions (Waters). The mixture was incubated at $55{ }^{\circ} \mathrm{C}$ for 10 min. After cooling down, one $\mu \mathrm{L}$ of each sample was used for separation and quantification in Acquity UPLC system (Waters). Reverse phase separation was performed with Waters BEH C18 column (100 mm x $2.1 \mathrm{~mm}$ i.d., $1.7 \mu \mathrm{m})$ at $46{ }^{\circ} \mathrm{C}$, with a flow rate of $0.7 \mathrm{~mL} \mathrm{~min}^{-1}$ ranging between eluents as follows: AccQ-Tag, Eluent B 10\%
(ACN), 100\% Milli-Q water and Eluent B 100\% $(\mathrm{ACN})$. The derivatized product was detected at $260 \mathrm{~nm}$. The amino acids histidine, serine, arginine, glycine, aspartate, glutamate, threonine, alanine, proline, cysteine, lysine, tyrosine, methionine, valine, isoleucine, leucine, and phenylalanine were determined based on the amino acid standard $\mathrm{H}$ (Prod NCI0180, Waters), as described by Schmidt et al. (2015).

\section{MINERAL CONTENT}

A $100 \mathrm{mg}$ sample of flour was used to determine the mineral content according to Badau et al. (2005). The quantification methods were: metavanadate colorimetric assay for phosphorus (P), atomic absorption spectrophotometry for calcium $(\mathrm{Ca})$, magnesium $(\mathrm{Mg})$, iron $(\mathrm{Fe})$, manganese $(\mathrm{Mn})$, copper $(\mathrm{Cu})$ and zinc $(\mathrm{Zn})$, flame photometry for potassium (K) and turbidimetry for sulfur $(\mathrm{S})$.

\section{STATISTICAL ANALYSIS}

The analysis of variance was performed with $\mathrm{F}$ (Snedecor) at a level of 5\%, for each quantitative trait and, where necessary, the LSD mean test was used at a level of $5 \%$.

\section{RESULTS}

The morphological traits of the African genotypes ENA1 and 2 were very different from the Indian genotype BRS1501 (Table I) as stated in the literature (Pimentel et al. 2003). ENA1 and ENA2 were taller, with a lower number of panicles per plant, but the panicles were longer than the panicles of the Indian genotype, BRS1501 (Table I), with

TABLE I

Plant height, number of panicles per plant, mean size of the panicles and cycle of three pearl millet cultivars.

\begin{tabular}{cccccc}
\hline Cultivars & Plant height $(\mathrm{m})$ & Number of tillers per plant & Number of panicles per plant & Mean size of panicles $(\mathrm{m})$ & Cycle \\
\hline ENA1 & $2.05 \mathrm{a}$ & $3.9 \mathrm{~b}$ & $1.70 \mathrm{~b}$ & $0.44 \mathrm{a}$ & 90 days \\
ENA2 & $2.19 \mathrm{a}$ & $4.4 \mathrm{ab}$ & $1.75 \mathrm{~b}$ & $0.50 \mathrm{a}$ & 94 days \\
BRS1501 & $1.50 \mathrm{~b}$ & $4.9 \mathrm{a}$ & $2.63 \mathrm{a}$ & $0.33 \mathrm{~b}$ & 95 days \\
\hline
\end{tabular}

Means followed by the same letter did not differ according to LSD test $(\alpha=0.05)$. 
TABLE II

Shoot fresh and dry weights at flowering and maturation $\left(\mathrm{kg} \mathrm{ha}^{-1}\right)$ and final grain yield $\left(\mathrm{kg} \mathrm{ha}^{-1}\right)$ of three pearl millet cultivars.

\begin{tabular}{ccc}
\hline \multirow{2}{*}{ Cultivars } & Fresh weigth & Dry weight \\
\cline { 2 - 3 } & \multicolumn{2}{c}{ Flowering } \\
\hline ENA1 & $21.533 \mathrm{a}$ & $4.933 \mathrm{a}$ \\
ENA2 & $22.733 \mathrm{a}$ & $5.200 \mathrm{a}$ \\
BRS1501 & $17.467 \mathrm{~b}$ & $3.867 \mathrm{~b}$ \\
\hline \multicolumn{2}{c}{ Harvest } \\
\hline ENA1 & $10.933 \mathrm{~b}$ & $3.200 \mathrm{~b}$ \\
ENA2 & $14.400 \mathrm{a}$ & $3.933 \mathrm{a}$ \\
BRS1501 & $11.533 \mathrm{~b}$ & $3.306 \mathrm{~b}$ \\
\hline & \multicolumn{2}{c}{ Yield } \\
\hline ENA1 & & $2.362 \mathrm{ab}$ \\
ENA2 & & $2.857 \mathrm{a}$ \\
BRS1501 & & $2.578 \mathrm{ab}$ \\
\hline
\end{tabular}

Means followed by the same letter did not differ according to LSD test $(\alpha=0.05)$.

all the three genotypes exhibiting the same grain yield (Table II). However, ENA1 and ENA2 plants produced higher fresh and dry weights than BRS1501 at flowering (Table II), whereas at harvest, the fresh and dry weights of ENA2 plants were significantly superior than for ENA1 and BRS1501 although all genotypes exhibited the same grain yield (Table II).

The crude protein content in grains was significantly higher in BRS1501 than in both ENA cultivars (Table III), with a higher content of albumins and prolamins than in ENA1 and ENA2, whist the opposite was observed for globulins and glutelins (Fig. 1).
The three pearl millet cultivars used differed only in SDS-PAGE bands for the glutelin protein fraction in which the BRS1501 exhibited higher intensity than ENA1 and ENA2 for two bands of 21 and $24 \mathrm{kDa}$ (Fig. 1). The main prolamin band was identified at $22 \mathrm{kDa}$ (Fig. 1).

The three millets cultivars exhibited similar contents of total amino acids, but the cultivar BRS1501 exhibited a lower proline content than ENA1 and ENA2 (Table IV).

The BRS1501 millet exhibited for all minerals evaluated, except $\mathrm{K}$, higher mineral content than ENA1 and ENA2 (Table V). The amount of Fe and $\mathrm{Zn}$ as well as the phytate content was also higher in cultivar BRS1501 than in both ENA cultivars (Table V).

\section{DISCUSSION}

Pearl millet has been cultivated in Brazil and presents several features in particular the high biomass and crude protein content, which not only is interesting in terms of use in sustainable agrosystem, but also for feeding livestock.

Comparing the morphological traits (Tables I and II) of the African genotypes, ENA1 and ENA2, to the Indian genotype BRS1501, chosen for this study, the African genotypes exhibited higher plant height and larger size of the panicles, but lower number of tillers and panicles per plant than the Indian genotype (Table I). However, the shoot fresh and dry weights at flowering, which can be used for no-till agriculture or for forage, as ray or silage, and at harvest, to be used as stover for livestock, were

TABLE III

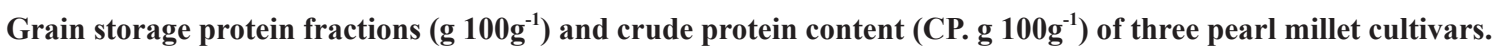

\begin{tabular}{cccccc}
\hline Cultivars & globulins & albumins & prolamins & glutelins & CP* \\
\hline ENA1 & $48.2 \mathrm{a}$ & $10.7 \mathrm{~b}$ & $21.4 \mathrm{~b}$ & $19.7 \mathrm{a}$ & $11.4 \mathrm{~b}$ \\
ENA2 & $48.1 \mathrm{a}$ & $11.5 \mathrm{~b}$ & $21.2 \mathrm{~b}$ & $19.2 \mathrm{a}$ & $12.0 \mathrm{~b}$ \\
BRS1501 & $43.9 \mathrm{~b}$ & $17.1 \mathrm{a}$ & $25.6 \mathrm{a}$ & $13.4 \mathrm{~b}$ & $17.6 \mathrm{a}$ \\
\hline
\end{tabular}

Means followed by the same letter did not differ according to LSD test $(\alpha=0.05)$.

* Total N x 6.2 . 


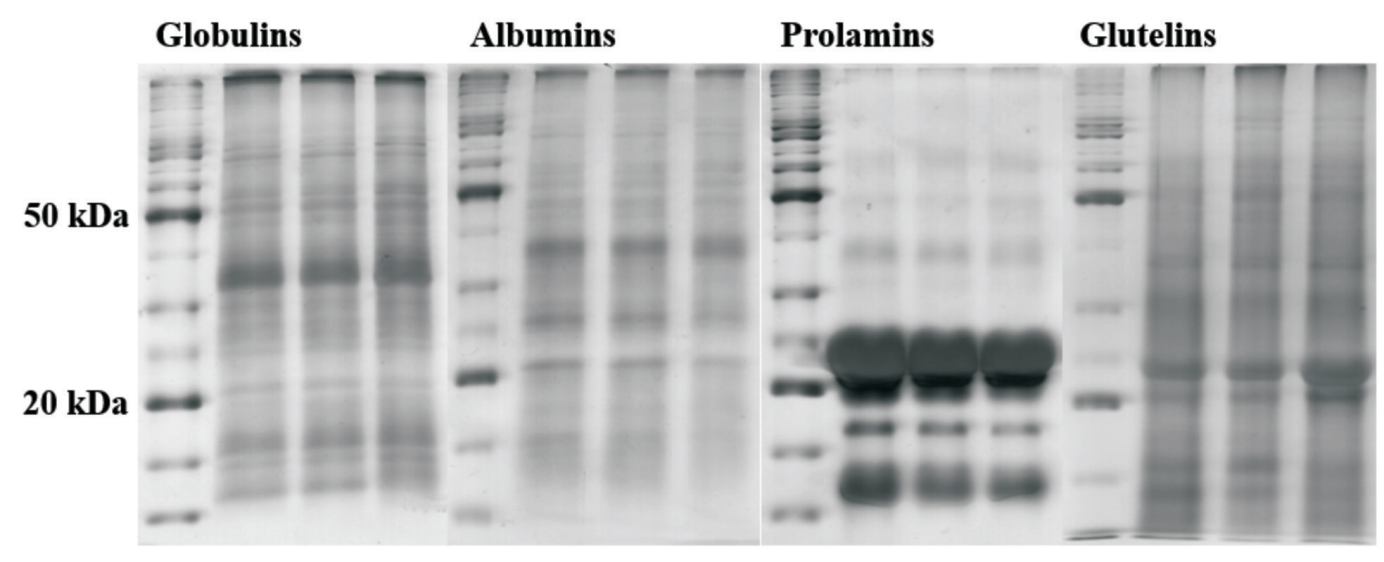

S ENA1 ENA2 BRS S ENA1 ENA2 BRS S ENA1 ENA2 BRS S ENA1 ENA2 BRS

Figure 1 - Profile of grain protein fractions of three pearl millets on SDS-polyacrylamide gels (S -standard, ENA1, ENA2 and BRS -BRS1501 - pearl millet cultivars).

TABLE IV

Total amino acid content ( $\mathrm{mg} \mathrm{g}^{-1}$ protein) in grains of three pearl millets cultivars.

\begin{tabular}{cccc}
\hline amino acid & ENA1 & ENA2 & BRS1501 \\
\hline His & $17.8 \mathrm{a}$ & $19.91 \mathrm{a}$ & $18.82 \mathrm{a}$ \\
Ser & $35.7 \mathrm{a}$ & $38.57 \mathrm{a}$ & $37.91 \mathrm{a}$ \\
Arg & $35.18 \mathrm{a}$ & $39.16 \mathrm{a}$ & $34.36 \mathrm{a}$ \\
Gly & $24.59 \mathrm{ab}$ & $25.9 \mathrm{a}$ & $21.75 \mathrm{~b}$ \\
Asp & $57.27 \mathrm{a}$ & $64.57 \mathrm{a}$ & $57.66 \mathrm{a}$ \\
Glu & $22915.55 \mathrm{a}$ & $25581.2 \mathrm{a}$ & $21892.88 \mathrm{a}$ \\
Thr & $29.93 \mathrm{a}$ & $26.53 \mathrm{a}$ & $27.23 \mathrm{a}$ \\
Ala & $55.63 \mathrm{a}$ & $60.44 \mathrm{a}$ & $51.94 \mathrm{a}$ \\
Pro & $47.19 \mathrm{a}$ & $50.36 \mathrm{a}$ & $43.08 \mathrm{~b}$ \\
Cys & $5.87 \mathrm{a}$ & $7.07 \mathrm{a}$ & $6.3 \mathrm{a}$ \\
Lys & $26.67 \mathrm{a}$ & $29.29 \mathrm{a}$ & $25.60 \mathrm{a}$ \\
Tyr & $28.9 \mathrm{a}$ & $29.43 \mathrm{a}$ & $26.13 \mathrm{a}$ \\
Met & $43.91 \mathrm{a}$ & $47.34 \mathrm{a}$ & $40.76 \mathrm{a}$ \\
Val & $44.08 \mathrm{a}$ & $46.76 \mathrm{a}$ & $43.59 \mathrm{a}$ \\
Ile & $33.38 \mathrm{a}$ & $35.56 \mathrm{a}$ & $30.64 \mathrm{a}$ \\
Leu & $76.02 \mathrm{a}$ & $82.43 \mathrm{a}$ & $69.53 \mathrm{a}$ \\
Phe & $42.80 \mathrm{a}$ & $42.16 \mathrm{a}$ & $37.12 \mathrm{a}$ \\
\hline
\end{tabular}

Means followed by the same letter did not differ according to LSD test $(\alpha=0.05)$.

higher for the two African genotypes than for the Indian genotype (Table II).

Another interesting finding was that although changes were observed among the genotypes, grain yield was the same for the three genotypes cultivated in the rainy season (Table II). However, when these genotypes were grown during the dry season, A.C.T. Costa (unpublished data) obtained higher grain yield for ENA2 than for ENA1 and BRS1501, which is probably because ENA2 was also shown to be more tolerant to rust, the principal disease for pearl millet cultivation (Pereira Filho et al. 2003), than ENA1 and BRS1501. The Indian genotype BRS1501 exhibited more panicles per plant than the African ENA1 and ENA2, which have a larger panicle (Table I), and possibly explains the similar results obtained for grain yield for all three genotypes under the conditions tested in this work (Table II).

The data current available in the literature show the same pattern presented in this work for grain crude protein content, where Indian pearl millet cultivar exhibited higher grain crude protein content than African millet cultivars. African pearl millets were evaluated by Nkama et al. (2005) and the grain quality trait varied from 71.9 to 120.5 $\mathrm{g} \mathrm{kg}^{-1}$, whilst Abdalla et al. (1998) in a distinct study with six African pearl millets detected grain protein content variation between 113 and $121 \mathrm{~g}$ $\mathrm{kg}^{-1}$. In the case of Brazilian pearl millet cultivars with Indian origin, Bastos et al. (2005) reported crude protein contents between 128.6 and $176.6 \mathrm{~g}$ 
TABLE V

Phytate content $\left(\mathrm{g} \mathrm{kg}^{-1}\right)$ and mineral $\left(\mathrm{g} \mathrm{kg}^{-1}\right)$ content in grains of the three pearl millets cultivars.

\begin{tabular}{cccc}
\hline Substance & ENA1 & ENA2 & BRS1501 \\
\hline phytate & $8.4 \mathrm{~b}$ & $8.7 \mathrm{~b}$ & $10.5 \mathrm{a}$ \\
$\mathbf{P}$ & $4.4 \mathrm{~b}$ & $3.8 \mathrm{c}$ & $4.9 \mathrm{a}$ \\
$\mathbf{K}$ & $3.3 \mathrm{a}$ & $3.0 \mathrm{a}$ & $3.9 \mathrm{a}$ \\
$\mathbf{C a}$ & $0.3 \mathrm{~b}$ & $0.3 \mathrm{~b}$ & $0.4 \mathrm{a}$ \\
$\mathbf{M g}$ & $1.1 \mathrm{~b}$ & $1.1 \mathrm{~b}$ & $1.3 \mathrm{a}$ \\
$\mathbf{S}$ & $0.9 \mathrm{~b}$ & $0.9 \mathrm{~b}$ & $1.3 \mathrm{a}$ \\
$\mathbf{C u}$ & $6.1 \mathrm{~b}$ & $5.9 \mathrm{~b}$ & $9.5 \mathrm{a}$ \\
$\mathbf{F e}$ & $53.8 \mathrm{~b}$ & $50.8 \mathrm{~b}$ & $97.1 \mathrm{a}$ \\
$\mathbf{M n}$ & $13.4 \mathrm{~b}$ & $12.1 \mathrm{~b}$ & $22.6 \mathrm{a}$ \\
$\mathbf{Z n}$ & $42.4 \mathrm{~b}$ & $39.0 \mathrm{~b}$ & $71.4 \mathrm{a}$ \\
\hline
\end{tabular}

Means followed by the same letter did not differ according to LSD test $(\alpha=0.05)$.

$\mathrm{kg}^{-1}$, much higher than the previous reports. Stover crude protein content ( $\mathrm{N}$ tissue content. 6.25) of ENA2 were around $6.77 \%$, very close to $7.0 \%$, which is considered the minimum level required for cattle maintenance (Pimentel et al. 2003). In addition, the crude protein content of the ENA2 grains were high $\left(130 \mathrm{~g} \mathrm{~kg}^{-1}\right)$ for a crop without $\mathrm{N}$ fertilization (Pimentel et al. 2003). Pearl millet has a deep and profusely developed root system, which exploits the deeper soil layers and can assimilate leached nutrients such as $\mathrm{N}$ to increase its $\mathrm{N}$ content (Bidinger et al. 2009). It is another common practice in Brazil to cultivate pearl millet during the dry winter after soybean cultivation in the summer to use and recycle the fertilization residues from the preceding culture (Pereira Filho 2003).

Previous work by Chandna and Matta (1990) revealed that the pearl millet seed storage proteins are very conserved, with little or no variation among genotypes, which has been confirmed in our study. Another similar pattern also observed by both our study and by Chandna and Matta (1990) is related to the similarity between the contents of prolamins and glutelins, even though our data indicated a prevalence of globulins (Fig. 1), while Chandna and Matta (1990) reported that prolamin and glutelin were co-dominating protein fractions. It seems that at least part of this difference in prevalent fractions could be attributed to the differences between the extraction methods used. The present study also showed low diversity for grain storage proteins separated on SDS-PAGE, in which pearl millet cultivars with different origins exhibited similar patterns of protein distribution, even though for total protein content as well as percentages of different fractions, they have shown more diversity. Yet, the main prolamin band identified in the present study with $22 \mathrm{kDa}$ (Fig. 1) is in accordance with the results reported by Gomez-Martınez (2012). Future studies should perhaps employ more detailed analysis of Pearl Millet storage proteins by using 2D-PAGE, as has been done for a wide range of crops species (Arruda et al. 2013, Vilhena et al. 2015, Schmidt et al. 2016).

The amino acid content was also shown to be similar to the one reported previously in the literature (Ravindran 1992). Proline is known for its high concentration in proteins of prolamine fraction in cereals (Shewry and Halford 2002). However, in this study it was not possible to establish a relationship between the cultivar with more prolamin content (BRS1501) and the cultivars with more proline (ENA1 and ENA2). Moreover, the cultivar BRS1501 exhibited higher total protein content, and this characteristic is not coincident with the percentage of the amino acid lysine, which exhibited no difference among cultivars, suggesting that there is little difference in the content of lysine among pearl millet cultivars. The identification of a high-lysine genotype is particularly important because cereal grains are deficient in this essential amino acid (Azevedo et al. 2006, Schmidt et al. 2016), and consequently would have a major impact in terms of the nutritional aspect of pearl millet grains. 
The breeding of cereals for a higher content of lysine is a very important goal particularly for developing countries, and the best example of a successful project is the one undertaken by the International Maize and Wheat Improvement Center (CIMMYT), that has achieved quality protein maize (QPM), which is used in several countries (Azevedo and Arruda 2010). In a similar manner, pearl millet breeding programs should also consider and give more attention to this aspect not only for lysine, but possibly for other essential amino acids.

It is interesting that in the study by Badau et al. (2005), ten African pearl millets were evaluated and none of them was shown to be superior in all minerals, i.e., whereas one was higher for $\mathrm{Ca}$ another was for $\mathrm{Fe}$ and so on. Overall, the range of mineral concentrations observed for the three pearl millet cultivars studied (Table V) were in line with previously reported data for other millet cultivars. For instance, the concentrations observed in this study are within the same range of those reported by Abdalla et al. (1998) and/or Badau et al. (2005) for all minerals, except $\mathrm{K}$, once Abdalla et al. (1998) reported about $0.09 \mathrm{~g} \mathrm{~kg}^{-1}$ for this mineral. On the other hand, Buerkert et al. (1998) reported $\mathrm{K}$ concentration similar to our data (between 3.0 and $3.71 \mathrm{~g} \mathrm{~kg}^{-1}$ ).

The pearl millet cultivars that showed the best concentration of Fe and $\mathrm{Zn}$ in the work of Govindaraj et al. (2013), were those that also exhibited Fe and $\mathrm{Zn}$ concentrations close to those obtained in this study (Table V), where hybrids cultivated in India exhibited ranges between 30 and $80 \mathrm{~g} \mathrm{~kg}^{-1} \mathrm{Fe}$ and the best parental line exhibited $102 \mathrm{mg} \mathrm{kg}^{-1} \mathrm{Fe}$. When $\mathrm{Zn}$ is concerned, Govindaraj et al. (2013) reported values in hybrids ranging between 31 to $70 \mathrm{mg} \mathrm{kg}^{-1}$, whereas the best parental line exhibited $84 \mathrm{mg} \mathrm{kg}^{-1}$ $\mathrm{Zn}$. The Fe and $\mathrm{Zn}$ concentrations in the genetic material are important for plant breeding since their genetic controls are predominantly additive and the environmental effect is less expressive. In addition, there is a positive correlation between $\mathrm{Fe}$ and $\mathrm{Zn}$ concentrations, indicating the effectiveness of simultaneous selection (Govindaraj et al. 2013).

The mineral concentration in grains is an important issue because more than two billion people, mainly in the developing world, suffer from micronutrient malnutrition, also known as "hidden hunger" (WHO/FAO 2000). Biofortification is one of the best approaches for addressing this global problem since it enhances the nutritional value of foods (Pimentel et al. 2003), whatever technique is used to produce such biofortified lines. One example of this major current efforts in the area of biofortification is the Harvest Plus program, from The Consultative Group on International Agricultural Research (CGIAR), that has been developing and distributing varieties of food staples (rice, wheat, maize, cassava, pearl millet, beans, and sweet potato) that contain higher Fe, $\mathrm{Zn}$ and provitamin A contents (Khush et al. 2012). Therefore, the data available on mineral content variability for the pearl millet lines studied is essential when recommending the ones to be used in breeding programs.

Phytate is mainly considered a common antinutritional factor in cereals (Badau et al. 2005, da Silva et al. 2011) and its detrimental effects include the reduction of protein and mineral absorption by the human body system and other monogastric (Cowieson et al. 2011). The reduction of protein and mineral absorption occurs due to a strong chelation of metals/minerals by phytic acid. However, some beneficial effects have also been reported, such as a reduction in blood glucose, cholesterol and triglycerides, which may reduce the risk of cancer and heart disease (Saleh et al. 2013). In addition, the detrimental effects of phytate are commonly reduced by food processing (Saleh et al. 2013). Although the data on phytate content for BRS1501, ENA1 and ENA2 (Table V) were shown to be within the same range as that observed by Badau et al. (2005), it was clear that the two distinct origins 
led to different contents and therefore some genetic variability exist that can be exploited in breeding programs.

The morphological traits evaluated in this study (Tables I and II) indicated that the African genotypes ENA1 and ENA2 are better than the Indian genotype BRS1501 for no-till farming or to produce forage with $15 \%$ of crude protein at flowering and at harvest (Table II) to produce stover (around 7\% of crude protein content) for livestock feeding (A.C.T. Costa, unpublished data, Pimentel et al. 2003). These behaviors would be expected since these cultivars retain their ancestral morphology, i.e., the African ones, ENA1 and ENA2, are higher, low-tillering and large-panicled, while the Indian one, BRS1501, is smaller, high-tillering and smallpanicled (A.C.T. Costa, unpublished data). Bidinger et al. (2009) also reported that pearl millet, from both origins, is considered one of the most water stress adapted cultivated species. However, while the grain yield was the same for the three genotypes (Table II), the crude protein content was higher for BRS1501 (Table III), which can be indicated for the production of chicken feed.

It is interesting that the agronomic and quality traits were convergent since the cultivar preferably chosen for grain production for manufacturing chicken feed, based on grain crude protein content, BRS1501, was also superior in amount of grain protein (Table III), and mineral concentration (Table V), whereas the cultivars of preference for biomass at flowering and harvest (Table II), ENA1 and ENA2, produced quality grains lower than BRS1501 for crude protein content and concentration mineral.

Despite their different origins, African (ENA1 and ENA2) or Indian (BRS1501), all these pearl millet cultivars exhibited very similar eletrophoretic pattern for protein storage, even though they differed in content for the distinct protein fractions. Based on the results, BRS1501 is better and more appropriate for grain production, since it exhibited higher content of total crude protein and minerals than ENA1 and ENA2, which are indicated for biomass production. Future studies must consider such differences and try to better understand the regulation of the metabolic pathways involved, especially when amino acids and proteins are concerned, to explore any genetic diversity existent and to produce better lines for commercial use.

\section{ACKNOWLEDGMENTS}

This research work was partially supported by the Fundação de Amparo à Pesquisa do Estado de São Paulo (FAPESP, Brazil, Grants 2012/500988 ) and by scholarships and fellowships from the Conselho Nacional de Desenvolvimento Científico e Tecnológico (CNPq). The authors are especially grateful to the $\mathrm{CBO}$ Laboratory Analyzes, who kindly performed the hydrolysis of the samples.

\section{REFERENCES}

ABDALLA AA, EL TINAY AH, MOHAMED BE AND ABDALLA AH. 1998. Effect of traditional processes on phytate and mineral content of pearl millet. Food Chem 63(1): 75-84.

ARRUDA SC, BARBOSA HS, AZEVEDO RA AND ARRUDA MA. 2013. Comparative studies focusing on transgenic through cp4EPSPS gene and non-transgenic soybean plants: an analysis of protein species and enzymes. J Proteomics 93: 107-116.

AZEVEDO RA AND ARRUDA P. 2010. High-lysine maize: the key discoveries that have made it possible. Amino Acids 39(4): 979-989.

AZEVEDO RA, LANCIEN M AND LEA PJ. 2006. The aspartic acid metabolic pathway, an exciting and essential pathway in plants. Amino Acids 30(2): 143-162.

BADAU MH, NKAMA I AND JIDEANI IA. 2005. Phytic acid content and hydrochloric acid extractability of minerals in pearl millet as affected by germination time and cultivar. Food Chem 92(3): 425-435.

BASTOS AO, MOREIRA I, FURLAN AC, FRAGA AL, OLIVEIRA RP AND OLIVEIRA E. 2005. Chemical Composition, Nutrients and Energy Digestibility of Pearl Millets (Pennisetum glaucum (1.) R. Brown) Fed to Growing Pigs. Rev Bras Zootecn 34(2): 520-528.

BIDINGER FR, YADAV OP AND WELTZIEN E. 2009. Genetic improvement of pearl millet for the arid zone of northwestern India: lessons from two decades of 
collaborative ICRISAT-ICAR research. Exp Agr 45(1): 107-115.

BLUM H, BEIER H AND GROSS HJ. 1987. Improved silver staining of plant proteins, RNA and DNA in polyacrylamide gels. Electrophoresis 8(2): 93-99.

BRADFORD MM. 1976. A rapid and sensitive method for the quantitation of microgram quantities of protein utilizing the principle of protein-dye binding. Anal Biochem 72(12): $248-254$

BUERKERT A, HAAKE C, RUCKWIED M AND MARSCHNER H. 1998. Phosphorus application affects the nutritional quality of millet grain in the Sahel. Field Crop Res 57: 223-235.

CHANDNA M AND MATTA NK. 1990. Characterization of pearl millet protein fractions. Phytochemistry 29(11): 3395-3399.

COWIESON AJ, WILCOCK P AND BEDFORD MR. 2011. Super-dosing effects of phytase in poultry and other monogastrics. Worlds Poult Sci J 67(2): 225-236.

DA SILVA A, PEREIRA T, COELHO CMM, DE ALMEIDA JÁ AND SCHMITT C. 2011. Seed phytate and protein content in beans depending on the application of basalt powder. Acta Sci Agron 33(1): 147-152.

FOUNTOULAKIS M AND LAHM HW. 1998. Hydrolysis and amino acid composition analysis of proteins. J Chromatogr A 826(2): 109-134.

GOMEZ-MARTINEZ D, ALTSKAR A AND STADING M. 2012. Correlation between viscoelasticity, microstructure, and molecular properties of zein and pennisetin melts. $\mathrm{J}$ Appl Polym Sci 125: 2245-2251.

GOVINDARAJ M, RAI KN, SHANMUGASUNDARAM P, DWIVEDI SL, SAHRAWAT KL, MUTHAIAH AR AND RAO AS. 2013. Combining ability and heterosis for grain iron and zinc densities in pearl millet. Crop Sci 53: 507517.

KHUSH G, LEE S, CHO JI AND JEON JS. 2012. Biofortification of crops for reducing malnutrition. Plant Biotechnol Rep 6: 195-202.

LANDRY J AND DAMERVAL C. 2000. Improved method for isolating and quantitating $\alpha$-amino nitrogen as nonprotein, true protein, salt-soluble proteins, zeins, and true glutelins in maize endosperm. Cereal Chem 77: 620-626.

LATTA M AND ESKIN M. 1980. A simple and rapid colorimetric method for phytate determination. J Agric Food Chem 28(6): 1313-1315.
NKAMA I, DRAME D, UGA CO, NDOYE A, KAKA S AND MANFUL J. 2005. Physical, chemical and dehulling characteristics of pearl millet cultivars grown in the West African sub-region. J Food Sci Tech 42(2): 188-191.

PATTANASHETTI SK, UPADHYAYA HD, DWIVEDI SL, VETRIVENTHAN M AND REDDY KN. 2016. Pearl millet. In: Genetic and genomic resources for grain cereals improvement. In: Singh M and Upadhyaya HD (Eds), Academic Press, Londres, p. 253-289.

PEREIRA FILHO IAP, FERREIRA AS, COELHO AM, CASELA CR, KARAM D, RODRIGUES JAS, CRUZ JC AND WAQUIL JM. 2003. Manejo da cultura do milheto. Circular Técnica, 29, Sete Lagoas: CNPMS-EMBRAPA, $17 \mathrm{p}$.

PIMENTEL C, GERALDO J, COSTA ACT, PEREIRA MB AND MAGALHÃES JR. 2003. Traits of nitrogen use efficiency for the selection of Pennisetum glaucum in an environment of nutrient limitations. Physiol Molec Biol Plants 9: 111-116.

SHEWRY PR AND HALFORD NG. 2002. Cereal seed storage proteins: structures, properties and role in grain utilization. J Exp Bot 53(370): 947-958.

SCHMIDT D, GAZIOLA SA, BOARETTO LF AND AZEVEDO RA. 2016. Proteomic analysis of mature barley grains from $\mathrm{C}$-hordein antisense lines. Phytochemistry 125: $14-26$.

SCHMIDT D, RIZZI V, GAZIOLA SA, MEDICI LO, VINCZE E, KOZAK M, LEA PJ AND AZEVEDO RA. 2015. Lysine metabolism in antisense C-hordein barley grains. Plant Physiol Bioch 87: 73-83.

RAVINDRAN G. 1992. Seed protein of millets: amino acid composition, proteinase inhibitors and in-vitro protein digestibility. Food Chem 44(1): 13-17.

SALEH ASM, ZHANG Q, CHEN J AND SHEN Q. 2013. Millet grains: nutritional quality, processing, and potential health benefits. Compr Rev Food Sci Food Saf 12(3): 281295.

VILHENA MB, FRANCO MR, SCHMIDT D, CARVALHO G AND AZEVEDO RA. 2015. Evaluation of protein extraction methods for enhanced proteomic analysis of tomato leaves and roots. An Acad Bras Cienc 87: 18531863.

WHO/FAO - WORLD HEALTH ORGANIZATION/ FOOD AND AGRICULTURE ORGANIZATION OF THE UNITED NATIONS. 2000. Guidelines on Food Fortification with Micronutrients. Geneva: WHO/FAO. 